\title{
Comparative fatty-acid profile and atherogenicity index of milk from free grazing Nguni, Boer and non-descript goats in South Africa
}

\author{
Emrobowansan M. Idamokoro ${ }^{1,2^{*}}$, Voster Muchenje ${ }^{1}$, Anthony J. Afolayan ${ }^{2}$ and Arno Hugo ${ }^{3}$
}

\begin{abstract}
This study aimed to determine and compare the fatty acid composition and atherogenecity index of milk fat from Nguni, Boer and non-descript at two different sampling periods. The goats ( $n=10$ for each goat genotypes) were raised under an extensive system of husbandry. Milk samples were collected from each individual goat to determine fatty acids, as methyl esters, using gas chromatography. The result revealed significant differences $(P<0.05)$ in fatty acid profiles among the three goat genotypes for butyric, caproic, myristic, palmitic, stearic, vaccenic, linoleic, conjugated linoleic, a-linolenic, arachidic, eicosatrienoic and docosapentaenoic acids, among other milk fats. The time of milk sampling also had a significant effect $(P<0.05)$ on caproic, lauric, myristic, palmitic, palmitoleic, margaric, stearic, linoleic, arachidonic, docosapentaenoic and conjugated linoleic acids of milk fat. In addition, Nguni goats' milk fat had a healthier fatty acid than those of Boer and non-descript goats, characterized by a lower content in saturated fatty acid $(68.65,73.77$ and $71.73(P<0.05)$, respectively). Goat genotypes and milk sampling time had an influence on the fatty acid composition of goat milk. These findings support the fact that goat milk is an important source of healthpromoting substances and support the sustainable use of animal genetic resources to improve goat milk fat quality, and hence deserve further investigation with local indigenous goat breeds.
\end{abstract}

Keywords: Milk fat, Saturated fatty acids, Indigenous goats, Lactation

\section{Introduction}

Milk from several livestock including cow, sheep and goats plays a significant economic role in the diet of people from time immemorial. Goat milk is known to be used for the production of different types of food such as traditional cheeses, ice cream and yoghurt (Atașo lu et al. 2009). The increased knowledge about the nutritional importance of milk has made it a global nutrient source in human diets. However, in addition to the nutritional value, the popularity of milk as an ideal natural food for humans has been enhanced, due to the presence of other bioactive properties, immunological properties and other countless

\footnotetext{
* Correspondence: mondayidamokoro@gmail.com; eidamokoro@ufh.ac.za ${ }^{1}$ Faculty of Science and Agriculture, Department of Livestock and Pasture Science, University of Fort Hare, Private Bag X1314, Alice 5700, South Africa ${ }^{2}$ MPED Research Center, Department of Botany, University of Fort Hare, Alice 5700 , South Africa

Full list of author information is available at the end of the article
}

benefits, based on its complex chemical constituents (Mills et al. 2011).

Considering the teeming population of people in developing countries, goat milk may form an ideal alternative food resource to curb malnutrition in these countries. Most rural areas in developing countries rear indigenous goats for meat, milk and skin among others reasons. In addition, a local dairy product made from goat milk, such as kefir, is used as a functional food and is presumed to be beneficial to human health in Indonesia (Thohari et al. 2012). However, the practice of using goat milk and its products as part of the family diet is rare in several parts of South Africa. According to Park (1994), milk from goats differ from that of cow milk in that it has better digestibility, alkalinity, buffering capacity and certain therapeutic values in medicine and human nutrition. 
The health benefits of milk are due to its nutrient composition including proteins (Mills et al. 2011), lactose, vitamins, minerals (Tsiplakou and Zervas 2008) and fats embedded in different proportions in the milk, and these constituents are dependent on different livestock species (Simopoulos 2002). Judging from the nutritional point of view, fatty acid (FA) composition is one of the essential components of milk with crucial health benefits when considering it as food for humans. In recent years, attention by researchers has focused on milk's fatty acid content and its diverse implications on human health.

Worthy of note is that several studies have reported findings on the use of supplementary feed to manipulate the composition of fatty acids in ruminant milk, so as to reduce any possible health risk of milk for human consumption (Chilliard and Ferlay 2004). Notwithstanding, there is scarcity in the number of studies that have reported findings on the fatty acid composition in milk of free-ranging goats, which mainly meet their nutrient requirements through grazing or browsing on available open land (veld in South Africa) (Tsiplakou et al. 2006; D'urso et al. 2008). Research of this nature is of particular significance to the sustainability of goat husbandry (as they depend very much on grazing), because grazing plays an important ecological role and contributes to the production of milk and its products in many countries. Furthermore, studies have shown that the fatty acid profile of animal milk fat is very important to consumers, due to its positive influence on human health (Mills et al. 2011). The present study was, therefore, aimed to determine and compare the changes in milk fatty acid composition and atherogenicity index of free-grazing indigenous South African goats at different milk sampling periods.

\section{Study area}

The study was conducted in the central eastern Cape Province of South Africa. The geographical location of the area falls within longitude $32^{\circ} 78^{\prime} \mathrm{E}$ and latitude $26^{\circ}$ $85^{\prime} \mathrm{S}$ with an altitude of about $450-500 \mathrm{~m}$ above sea level and a mean annual rainfall of $480 \mathrm{~mm}$. The annual mean temperature of the area is about $18.7^{\circ} \mathrm{C}$. Before the start of the study, an ethical clearance certificate (MUC0815IDA01) was obtained from the University of Fort Hare. The study was carried out between the months of May and September 2016. The area lies in the False Thornveld of the eastern Cape of South Africa, which is historically known to be heavily stocked with ruminant animals including goats, sheep and cattle on a yearly basis (Mucina and Rutherford 2011). The major vegetation of the area includes grass species such as Cympopogon plurinodis, Sporobolus africanus, Aristida congesta, Cynodon dactylon, Themeda triandra, Sporobolus fimbriatus, Digitaria eriantha and Eragrostis. The predominant tree plants in the area are Vachellia karroo (Acacia karroo), Maytenus polyacantha and Scutia myrtina (Mucina and Rutherford 2011; Idamokoro et al. 2016). Goats are customarily allowed to browse and graze in the morning hours $(0900 \mathrm{~h})$ and are returned to their kraals (enclosures) before sunset (at about $1600 \mathrm{~h}$ ) usually by a herd man. The area is characterized by different seasons including winter (May-July), spring (August-September), summer (October-January) and autumn (February-April).

\section{Material and methods}

Experimental animals

A total of 30 healthy goats from three different genotypes, namely Nguni (10), non-descripts (10) and Boer (10), were randomly selected from local goat farmers. The goats used for the study were selected and monitored during their late trimester until their late lactation period which spanned the 5 months of the study investigation. A pregnancy diagnosis test was carried out on the goats to determine their stage of pregnancy using an ultra-scanning machine (Colour Doppler Ultrasound System for Veterinary; model number: EC30 Vet; Zhuhai Ecare Electronics Science and Technology Co., Ltd., Beijing, China). The average age of all the goats used in the study was 5 years, and the selected goats have kidded at least once before. The average weight of the goats was $40.07 \mathrm{~kg}$.

\section{Milk sample collection}

Milk samples were collected from non-dairy goat breeds (i.e. Nguni (10), non-descripts (10) and Boer (10) goats) within a $40-\mathrm{km}$ radius within the study site at central Eastern Cape, South Africa. Milk samples were collected by hand milking once a day (between 0800 and $0900 \mathrm{~h}$ ) from the different goat genotypes. Before milking, goat teats were cleaned with cotton wool and methylated spirit to remove any form of dirt. Milk samples of about $45 \mathrm{ml}$ were collected in a $50-\mathrm{ml}$ sterile plastic bottle and kept in a cooler box before taking them to the laboratory for analyses. Milk samples were collected twice at two sampling periods during lactation which represents the early and late lactation periods (i.e. at weeks 2 and 6).

\section{Determination of fatty acid in milk}

The method of Folch et al. (1957) was used to determine the total lipid from milk samples using methanol and chloroform in a ratio of $1: 2$. A concentration $(0.001 \%)$ of butylated hydroxy-toluene was added to the methanol and chloroform mixture to obtain fat extracts. Fat extracts in a vacuum were dried in a rotary evaporator and again dried overnight using phosphorus pentoxide as moisture adsorbent in an oven (in a vacuum) at $50{ }^{\circ} \mathrm{C}$ (Nantapo et al. 2014). The total extractable fat content 
(EFC) of the milk samples was determined by means of gravity and was expressed as \% fat $(w / w)$ per $100 \mathrm{~g}$ of milk. The fat-free dry matter (FFDM) content of milk was determined after the extraction of fat content, and the residue weighed on a filter paper after drying. The FFDM was calculated using the difference in weight of the initial milk sample before and after drying in the oven, and it was expressed as \% FFDM $(w / w)$ per $100 \mathrm{~g}$ milk. The moisture content of the milk sample was obtained using the formula as follows: $100 \%$ - \% lipid - \% FFDM. The moisture content was expressed as \% moisture $(w / w)$ per $100 \mathrm{~g}$ of the milk sample. From the extracted fat, 10 $\mathrm{mg}$ of total lipid was transferred by means of a disposable glass Pasteur pipette into a Teflon-lined screw-top test tube. Fatty acids were determined from the fat extracts by trans-esterification to form methyl esters using the method as described by Park and Goins (1994). This was done by using $0.5 \mathrm{~N}$ of $\mathrm{NaOH}$ in a mixture of $14 \%$ boron trifluoride and methanol solution. The fatty acids in the milk sample extracts were then quantified using a Varian GX 3400 GC with a flame ionization detector, by means of a fused silica capillary column, Chrompack CPSIL 88 (100-m length, $0.25-\mu \mathrm{m}$ ID with $0.2-\mu \mathrm{m}$ film thicknesses). The column temperature used for the fatty acids in milk ranged between 40 and $230{ }^{\circ} \mathrm{C}$ (hold $2 \mathrm{~min} ; 4^{\circ} \mathrm{C} / \mathrm{min}$; hold $10 \mathrm{~min})$. After quantification of fatty acid methyl esters, $1 \mu$ of the sample in hexane was injected into the column (using a Varian 8200 CX autosampler) in a ratio of 100:1. The temperature of the injection port and the detector was maintained at $250{ }^{\circ} \mathrm{C}$. Nitrogen was used as the make-up gas while hydrogen, at $45 \mathrm{psi}$, was used as the carrier gas. The chromatograms were recorded using a chromatography software known as Varian Star Chromatography Software. The fatty acid methyl ester (FAME) samples were recognized by means of comparing the relative retention times of the FAME peaks from samples obtained from the that of the standards i.e. from Sigma (Sigma-Aldrich, St. Louis, MO) (18919). Additional CLA standards were gotten from Matreya, Inc. (Pleasant Gap, PA) which include the following: trans-10, cis-12 18:2 isomers, trans-9, trans-11, cis- 9 , cis- 11 , cis- 9 , trans- 11 . The fatty acid from the milk samples were calculated as the relative \% of each separate fatty acid as a percentage of the total of all fatty acids found in the sample. Other known fatty acid combinations and ratios were expressed by using the fatty acid data including total polyunsaturated fatty acids (PUFA), total omega- 3 fatty acids, total omega- 6 fatty acids, total saturated fatty acids (SFA), total monounsaturated fatty acids (MUFA), PUFA/SFA and omega-6/ omega-3 fatty acid ratio. Atherogenicity index was calculated as the content ratio of SFA/unsaturated FA, using the following formula proposed by Ulbricht and Southgate (1991): atherogenicity index: [C12 + 4 (C14) + C16]: (sum of unsaturated FA).

\section{Statistical analysis}

Data were analyzed using the general linear model procedure of the Statistical Analysis System (version 1.9 of 2007). Significant differences between the least square means for genotypes and lactation stages on fatty acid composition and atherogenicity index were performed using the PDIFF procedure of SAS. The model used is given below:

$$
Y i j k=\mu+G i+P j+(G i P j)+e i j k
$$

where $Y i j k=$ fatty acid composition and atherogenicity index of the milk samples

$\mu=$ overall mean

$G i=$ effect of the $i$ th goat genotype (Nguni, Boer, non-descript)

$P j=$ effect of the $j$ th milk sampling time (weeks 2 and 6)

$G i P j=$ interaction between goat genotypes and milk sampling time

$e i j k=$ random error

\section{Results}

The results of the study showed that goat genotypes had a significant influence $(P<0.05)$ on fat content of the milk (Table 1). The milk of non-descript goats had a higher mean value of fat content compared with those of Nguni and Boer goats (Table 1). The time of milk sampling had no significant influence on the fat content, fat-free dry matter content and moisture content of milk. In addition, there were no significant interactions between goat genotypes and the time of milk sampling (weeks 2 and 6) on the fat content, fat-free dry matter content and moisture content of the milk (Table 1).

Likewise, goat genotypes had a significant influence $(P<0.05)$ on butyric, caproic, myristic, pentadecylic, palmitic, stearic, elaidic, oleic, vaccenic, linolelaidic, linoleic, conjugated linoleic, $\alpha$-linolenic, arachidic, eicosatrienoic, arachidonic, eicosopentaenoic, heneicosanoic and docosapentaenoic acids of milk as seen in Table 2. The milk from non-descript goat had higher mean values of butyric, caproic, myristic, pentadecylic, linoleic, $\alpha$-linolenic, arachidic, eicosatrienoic, arachidonic, heneicosanoic and docosapentaenoic acids when compared with those from Nguni and Boer goats. Furthermore, the milk from Nguni goats had higher mean value of stearic, elaidic, oleic, vaccenic, linolelaidic and conjugated linoleic acids when compared with those from Boer and non-descript goats. Conversely, the milk from Boer goats had higher palmitic acid compared with those from Nguni and non-descript goats (Table 2).

The time of milk sampling had a significant effect $(P<0.05)$ on milk caproic, caprylic, capric, lauric, myristic, palmitic, palmitoleic, margaric, stearic, oleic, 
Table 1 Effect of genotype, lactation stage and interaction between genotype and lactation stage on milk composition of freeranging indigenous goats

\begin{tabular}{|c|c|c|c|c|c|c|c|c|}
\hline \multirow[t]{2}{*}{ Items (g/100 g milk) } & \multicolumn{3}{|l|}{ Genotype } & \multicolumn{2}{|c|}{ Lactation stage } & \multicolumn{3}{|l|}{$P$ value } \\
\hline & Nguni (10) & Boer (10) & Non-descript (10) & Early & Late & $\bar{G}$ & $\mathrm{~L}$ & $\mathrm{G} \times \mathrm{L}$ \\
\hline Fat content & $4.30^{\mathrm{a}} \pm 0.47$ & $2.28^{\mathrm{b}} \pm 0.75$ & $4.56^{a} \pm 0.55$ & $3.79^{\mathrm{a}} \pm 0.49$ & $3.64^{a} \pm 0.49$ & 0.0484 & 0.9527 & 0.8492 \\
\hline Fat-free dry matter content & $9.00^{a} \pm 0.52$ & $9.26^{a} \pm 0.83$ & $10.12^{\mathrm{a}} \pm 0.60$ & $9.79^{a} \pm 0.54$ & $9.13^{\mathrm{a}} \pm 0.54$ & 0.3713 & 0.3924 & 0.9772 \\
\hline Moisture content & $86.64^{a} \pm 0.75$ & $88.44^{a} \pm 1.20$ & $85.30^{\mathrm{a}} \pm 0.88$ & $86.40^{\mathrm{a}} \pm 0.79$ & $87.22^{a} \pm 0.78$ & 0.1147 & 0.4623 & 0.934 \\
\hline
\end{tabular}

Mean $( \pm$ S.E.) values within rows with different superscripts differ significantly $(P<0.05)$ between genotypes and lactation stages

S.E. standard error

Table 2 Effect of genotype, lactation stage and interaction between genotype and lactation stage on fatty acid relative to total \% fatty acid content of free-ranging indigenous goats

\begin{tabular}{|c|c|c|c|c|c|c|c|c|}
\hline \multirow{2}{*}{$\begin{array}{l}\text { FAME (\% of total } \\
\text { fatty acid ratio) }\end{array}$} & \multicolumn{3}{|l|}{ Genotype } & \multicolumn{2}{|c|}{ Lactation stage } & \multicolumn{3}{|l|}{$P$ value } \\
\hline & Nguni (10) & Boer (10) & Non-descript (10) & Early & Late & $\mathrm{G}$ & $L$ & $G \times L$ \\
\hline Butyric & $0.66^{b} \pm 0.02$ & $0.69^{\mathrm{ab}} \pm 0.03$ & $0.76^{a} \pm 0.02$ & $0.73^{a} \pm 0.02$ & $0.68^{a} \pm 0.02$ & 0.0300 & 0.2116 & 0.8995 \\
\hline Caproic & $1.47 \pm 0.04$ & $1.60 \pm 0.07$ & $1.64 \pm 0.05$ & $1.49^{b} \pm 0.04$ & $1.66^{\mathrm{a}} \pm 0.04$ & 0.0390 & 0.0113 & 0.1959 \\
\hline Caprylic & $2.23^{a} \pm 0.09$ & $2.43^{a} \pm 0.15$ & $2.58^{\mathrm{a}} \pm 0.11$ & $2.14^{b} \pm 0.10$ & $2.69^{a} \pm 0.10$ & 0.0835 & 0.0004 & 0.2603 \\
\hline Capric & $8.23^{a} \pm 0.41$ & $9.32^{a} \pm 0.66$ & $9.44^{a} \pm 0.48$ & $7.57^{b} \pm 0.43$ & $10.43^{a} \pm 0.43$ & 0.1314 & 0.0001 & 0.2320 \\
\hline Hendecanoic & $0.01^{a} \pm 0.004$ & $0.01^{\mathrm{a}} \pm 0.007$ & $0.01^{a} \pm 0.005$ & $0.01^{a} \pm 0.004$ & $0.02^{a} \pm 0.004$ & 0.4672 & 0.2719 & 0.1523 \\
\hline Lauric & $3.39^{a} \pm 0.18$ & $3.80^{a} \pm 0.29$ & $3.83^{a} \pm 0.21$ & $3.18^{b} \pm 0.19$ & $4.17^{\mathrm{a}} \pm 0.19$ & 0.2427 & 0.0006 & 0.1633 \\
\hline Tridecoic & $0.01^{\mathrm{a}} \pm 0.004$ & $0.02^{\mathrm{a}} \pm 0.007$ & $0.02^{\mathrm{a}} \pm 0.005$ & $0.02^{\mathrm{a}} \pm 0.004$ & $0.02^{a} \pm 0.005$ & 0.1187 & 0.9308 & 0.9036 \\
\hline Myristic & $7.90^{c} \pm 0.33$ & $9.49^{\mathrm{ab}} \pm 0.54$ & $9.56^{a} \pm 0.39$ & $8.20^{b} \pm 0.35$ & $9.77^{\mathrm{a}} \pm 0.35$ & 0.0038 & 0.0027 & 0.6084 \\
\hline Myristoleic & $0.03^{a} \pm 0.009$ & $0.01^{a} \pm 0.01$ & $0.04^{a} \pm 0.01$ & $0.02^{a} \pm 0.01$ & $0.03^{a} \pm 0.01$ & 0.2323 & 0.6065 & 0.0965 \\
\hline Pentadecylic & $0.82^{c} \pm 0.03$ & $0.88^{b c} \pm 0.05$ & $1.03^{\mathrm{a}} \pm 0.04$ & $0.88^{\mathrm{a}} \pm 0.03$ & $0.94^{\mathrm{a}} \pm 0.03$ & 0.0008 & 0.2457 & 0.1756 \\
\hline Palmitic & $24.79^{c} \pm 0.36$ & $27.99^{\mathrm{a}} \pm 0.59$ & $26.07^{b} \pm 0.43$ & $25.61^{b} \pm 0.38$ & $26.94^{a} \pm 0.38$ & 0.0001 & 0.0179 & 0.7137 \\
\hline Palmitoleic & $0.47^{\mathrm{a}} \pm 0.02$ & $0.48^{a} \pm 0.04$ & $0.56^{a} \pm 0.33$ & $0.56^{a} \pm 0.03$ & $0.45^{b} \pm 0.02$ & 0.0905 & 0.0127 & 0.0641 \\
\hline Margaric & $0.81^{a} \pm 0.02$ & $0.86^{\mathrm{a}} \pm 0.04$ & $0.89^{\mathrm{a}} \pm 0.03$ & $0.97^{\mathrm{a}} \pm 0.02$ & $0.74^{b} \pm 0.02$ & 0.1606 & 0.0001 & 0.0070 \\
\hline Heptadecenoic & $0.19^{\mathrm{a}} \pm 0.02$ & $0.19^{\mathrm{a}} \pm 0.04$ & $0.23^{a} \pm 0.03$ & $0.23^{a} \pm 0.02$ & $0.18^{a} \pm 0.02$ & 0.6887 & 0.1581 & 0.2746 \\
\hline Stearic acid & $17.92^{\mathrm{a}} \pm 0.48$ & $16.19^{b c} \pm 0.76$ & $15.26^{\mathrm{c}} \pm 0.56$ & $17.33^{\mathrm{a}} \pm 0.50$ & $15.59^{b} \pm 0.49$ & 0.0024 & 0.0173 & 0.6811 \\
\hline Elaidic & $0.20^{\mathrm{a}} \pm 0.01$ & $0.06^{c} \pm 0.02$ & $0.15^{b} \pm 0.01$ & $0.13^{\mathrm{a}} \pm 0.01$ & $0.14^{\mathrm{a}} \pm .01$ & 0.0001 & 0.7794 & 0.0455 \\
\hline Oleic & $26.59^{\mathrm{a}} \pm 1.04$ & $21.90^{b c} \pm 1.66$ & $22.64^{c} \pm 0.1 .22$ & $26.25^{\mathrm{a}} \pm 1.09$ & $21.16^{b} \pm 1.08$ & 0.0174 & 0.0017 & 0.174 \\
\hline Vaccenic & $0.43^{\mathrm{a}} \pm 0.02$ & $0.25^{b c} \pm 0.03$ & $0.26^{c} \pm 0.02$ & $0.29^{\mathrm{a}} \pm 0.02$ & $0.33^{a} \pm 0.02$ & 0.0001 & 0.2171 & 0.0006 \\
\hline Linolelaidic & $0.21^{\mathrm{a}} \pm 0.01$ & $0.07^{b c} \pm 0.02$ & $0.11^{b} \pm 0.01$ & $0.11^{\mathrm{a}} \pm 0.01$ & $0.15^{\mathrm{a}} \pm 0.01$ & 0.0001 & 0.0524 & 0.0064 \\
\hline Linoleic & $1.26^{\mathrm{c}} \pm 0.08$ & $1.78^{b c} \pm 0.12$ & $1.97^{\mathrm{a}} \pm 0.09$ & $1.82^{\mathrm{a}} \pm 0.08$ & $1.52^{b} \pm 0.08$ & 0.0001 & 0.0134 & 0.0444 \\
\hline Conjugated linoleic acid & $0.63^{\mathrm{a}} \pm 0.04$ & $0.16^{c} \pm 0.06$ & $0.53^{\mathrm{ab}} \pm 0.04$ & $0.38^{b} \pm 0.04$ & $0.50^{\mathrm{a}} \pm 0.04$ & 0.0001 & 0.0465 & 0.0012 \\
\hline a-Linolenic & $1.09^{c} \pm 0.06$ & $1.12^{\mathrm{bc}} \pm 0.10$ & $1.40^{\mathrm{a}} \pm 0.07$ & $1.26^{\mathrm{a}} \pm 0.07$ & $1.15^{\mathrm{a}} \pm 0.07$ & 0.0126 & 0.2882 & 0.0063 \\
\hline Nonoadecanoic & $0.11^{a} \pm 0.01$ & $0.13^{a} \pm 0.02$ & $0.10^{\mathrm{a}} \pm 0.01$ & $0.11^{a} \pm 0.01$ & $0.12^{\mathrm{a}} \pm 0.01$ & 0.4942 & 0.5195 & 0.3870 \\
\hline Arachidic & $0.18^{c} \pm 0.02$ & $0.29^{b} \pm 0.03$ & $0.39^{\mathrm{a}} \pm 0.02$ & $0.30^{\mathrm{a}} \pm 0.02$ & $0.27^{\mathrm{a}} \pm 0.02$ & 0.0001 & 0.4291 & 0.3246 \\
\hline Eicosatrienoic & $0.04^{b c} \pm 0.007$ & $0.05^{b} \pm 0.01$ & $0.12^{a} \pm 0.009$ & $0.07^{a} \pm 0.008$ & $0.07^{a} \pm 0.008$ & 0.0001 & 0.8894 & 0.7003 \\
\hline Arachidonic & $0.03^{c} \pm 0.006$ & $0.06^{\mathrm{ab}} \pm 0.01$ & $0.07^{\mathrm{a}} \pm 0.007$ & $0.06^{a} \pm 0.006$ & $0.04^{\mathrm{b}} \pm .006$ & 0.0040 & 0.0223 & 0.9616 \\
\hline Eicosopentaenoic & $0.05^{\mathrm{a}} \pm 0.006$ & $0.01^{b c} \pm 0.009$ & $0.03^{b} \pm 0.007$ & $0.04^{a} \pm 0.006$ & $0.02^{\mathrm{a}} \pm 0.006$ & 0.0102 & 0.1031 & 0.8608 \\
\hline Heneicosanoic & $0.04^{b} \pm 0.006$ & $0.02^{b c} \pm 0.01$ & $0.08^{\mathrm{a}} \pm 0.007$ & $0.04^{a} \pm 0.006$ & $0.05^{\mathrm{a}} \pm 0.006$ & 0.0001 & 0.3325 & 0.1608 \\
\hline Docosapentaenoic & $0.07^{b} \pm 0.009$ & $0.04^{b c} \pm 0.01$ & $0.09^{\mathrm{a}} \pm 0.01$ & $0.09^{a} \pm 0.009$ & $0.05^{b} \pm 0.009$ & 0.0176 & 0.0195 & 0.3499 \\
\hline
\end{tabular}


linoleic, conjugated linoleic, arachidonic and docosapentaenoic acids (Table 2). The milk during the second sampling period (6 weeks in lactation) had a higher mean value of caproic, caprylic, capric, lauric, myristic, palmitic and conjugated linoleic acids when compared with that of the first sampling period (2 weeks in lactation). Furthermore, the milk of the first sampling period (2 weeks in lactation) had a higher mean value of palmitoleic, margaric, stearic, oleic, linoleic, arachidonic and docosapentaenoic acids when compared with that of the second sampling period (Table 2). There was a significant interaction between goat genotypes and sampling times on margaric, elaidic, vaccenic, linolelaidic, linoleic, conjugated linoleic and $\alpha$-linolenic acids of goat milk (Table 2).

The results in Table 3 showed that goat genotypes had a significant influence $(P<0.05)$ on the milk total saturated fatty acids, total monosaturated fatty acids, total polyunsaturated fatty acids, total omega- 6 fatty acids, total omega-3 fatty acids and the ratio of total polyunsaturated fatty acids and total saturated fatty acids (PUFA/ SFA). The milk from non-descript goats had higher mean value of total polyunsaturated fatty acids, total omega- 6 fatty acids, total omega- 3 fatty acids and the ratio of total polyunsaturated fatty acids and total saturated fatty acids compared with those from Nguni and Boer goats. Likewise, the milk of Nguni goats had higher mean value of total monounsaturated fatty acids when compared with those of Boer and non-descript goats. Table 3 also shows that the milk of Boer goats had a higher mean value of total saturated fatty acids when compared with those of Nguni and non-descript goats. There was no significant influence on the mean value of milk for total saturated fatty acids of Boer and non-descript goats.

The time of milk sampling had a significant effect $(P<0.05)$ on the total saturated fatty acids, the total monounsaturated fatty acids and the ratio of total polyunsaturated fatty acids and total saturated fatty acids of goat milk (Table 3). The time of the first milk sampling (2 weeks in lactation) had higher mean values in the total monounsaturated fatty acids and ratio of total polyunsaturated fatty acids and total saturated fatty acids when compared with that of the second milk sampling period. Conversely, the milk of the second sampling period (6 weeks in lactation) had a higher mean value of total saturated fatty acids compared with that of the first milk sampling period. In addition, there was a significant interaction between goat genotypes and the different milk sampling times (i.e. 2 and 6 weeks in lactation) on the total omega- 3 fatty acids and ratio of n-6/n-3 fatty acids of milk fat of goats (Table 3 ).

\section{Discussion}

The purpose of the present study was to determine and compare the changes in the fatty acid profile and atherogenicity index of free-ranging indigenous South African goats (Nguni, Boer and non-descript goats) at different sampling periods. The husbandry of goats was based on an extensive system of production. To date, no previous data on the fatty acid composition of milk fat of Nguni, Boer and non-descript goat breeds is available in the literature. Conversely, several studies have reported the effect of breeds on milk fatty acid profile in other livestock such as ewes (Talpur et al. 2009) and cows (Myburgh et al. 2012). However, most studies have focused on evaluating the effect of diet on fatty acid profile of milk fat in livestock (Bouattour et al. 2008; Tyagi et al. 2010). Assessing the influence of breed on the fatty acid composition of milk fat has not been considered a priority. The reason for this can be explained by the fact that each breed, and indigenous ones in particular, are of interest only in the geographical area where they are raised. According to Silanikove et al. (2010), milk from goats grazing on rangeland may present an ignored "treasure trove" with respect to the presence of health-promoting lipids found in them.

Table 3 Effect of genotype, lactation stage and interaction between genotype and lactation stage on selected classes of fatty acid, ratios and atherogenicity index of milk from free-ranging indigenous goats

\begin{tabular}{|c|c|c|c|c|c|c|c|c|}
\hline \multirow[t]{2}{*}{ Fatty acid ratios } & \multicolumn{3}{|l|}{ Genotype } & \multicolumn{2}{|l|}{ Lactation } & \multicolumn{3}{|l|}{$P$ value } \\
\hline & Nguni (10) & Boer (10) & Non-descript (10) & Early & Late & G & $\mathrm{L}$ & $G \times L$ \\
\hline Total saturated fatty acids (SFA) & $68.65^{c} \pm 1.08$ & $73.77^{\mathrm{a}} \pm 1.73$ & $71.73^{\mathrm{ab}} \pm 1.27$ & $68.62^{b} \pm 1.14$ & $74.14^{a} \pm 1.12$ & 0.0319 & 0.0011 & 0.2455 \\
\hline Total monounsaturated fatty acids (MUFA) & $27.92^{\mathrm{a}} \pm 1.07$ & $22.90^{\mathrm{bc}} \pm 1.72$ & $23.90^{\mathrm{b}} \pm 1.25$ & $27.51^{a} \pm 1.13$ & $22.31^{\mathrm{b}} \pm 1.11$ & 0.0159 & 0.0019 & 0.1958 \\
\hline Total polyunsaturated fatty acids (PUFA) & $3.41^{b} \pm 0.14$ & $3.31^{b c} \pm 0.23$ & $4.35^{\mathrm{a}} \pm 0.17$ & $3.86^{\mathrm{a}} \pm 0.15$ & $3.53^{\mathrm{a}} \pm 0.15$ & 0.0001 & 0.1392 & 0.0626 \\
\hline Total omega- 6 fatty acids (n-6) & $2.19^{b} \pm 0.09$ & $2.13^{b c} \pm 0.14$ & $2.82^{\mathrm{a}} \pm 0.10$ & $2.46^{a} \pm 0.09$ & $2.30^{\mathrm{a}} \pm 0.09$ & 0.0001 & 0.2214 & 0.2725 \\
\hline Total omega-3 fatty acids (n-3) & $1.22^{b} \pm 0.07$ & $1.19^{b c} \pm 0.11$ & $1.53^{\mathrm{a}} \pm 0.08$ & $1.39^{\mathrm{a}} \pm 0.07$ & $1.23^{\mathrm{a}} \pm 0.07$ & 0.0117 & 0.1448 & 0.0110 \\
\hline PUFA/SFA & $0.05^{b} \pm 0.002$ & $0.04^{b c} \pm 0.003$ & $0.06^{\mathrm{a}} \pm 0.002$ & $0.05^{\mathrm{a}} \pm 0.002$ & $0.04^{b} \pm 0.002$ & 0.0059 & 0.0337 & 0.1032 \\
\hline$n-6 / n-3$ & $1.91^{\mathrm{a}} \pm 0.07$ & $1.83^{\mathrm{a}} \pm 0.12$ & $1.94^{\mathrm{a}} \pm 0.09$ & $1.94^{\mathrm{a}} \pm 0.08$ & $1.94^{\mathrm{a}} \pm 0.08$ & 0.7753 & 0.4989 & 0.0075 \\
\hline Atherogenicity index & $2.34^{\mathrm{a}} \pm 0.17$ & $2.60^{a} \pm 0.027$ & $2.35^{\mathrm{a}} \pm 0.20$ & $2.39^{a} \pm 0.17$ & $2.39^{\mathrm{a}} \pm 0.17$ & 0.7025 & 0.7050 & 0.2118 \\
\hline
\end{tabular}

Mean $( \pm$ S.E.) values within rows with different superscripts differ significantly $(P<0.05)$ between genotypes and lactation stages S.E. standard error 
Or study found that goat genotypes had a significant influence $(P<0.05)$ on conjugated linoleic acid. Nguni goats had a higher mean value of conjugated linoleic acids when compared with Boer and non-descript goats. Breed effect on milk fat conjugated linoleic acid content has been reported previously both in cows (Pesek et al. 2005) and in ewes (Talpur et al. 2009). However, studies on the effect of breed on conjugated linoleic acid for goats are scanty. On the contrary, Tsiplakou et al. (2006), in their study, did not observe breed effect on the conjugated linoleic acid of milk from four sheep breeds that were maintained under identical feeding conditions.

The time of milk sampling (2 and 6 weeks in lactation) had a significant $(P<0.05)$ influence on caproic, caprylic, capric, lauric, palmitic, palmitoleic, margaric, oleic, linoleic and conjugated linoleic acids as observed from the current study. In line with our findings, Atașo lu et al. (2009) in their study also reported significant influence of milk sampling time on milk fat for oleic, stearic, capric, lauric, linoleic, linolenic and conjugated linoleic acids. Furthermore, D'urso et al. (2008), in their study, reported significant variations in some fatty acid profiles (especially, conjugated linoleic acid) at different milk sampling times. However, contrary to our findings, Tsiplakou and Zervas (2013) observed that there was no significant difference in the time of milk sampling and milk fat of caproic, caprylic, capric, lauric, palmitic, palmitoleic, margaric, oleic, linoleic and conjugated linoleic acids. The reason for the variations as observed in the different studies may not be clearly understood, but could be linked to the different goat breeds used in these studies. Several studies have reported the effect of breeds on the fatty acid profiles of goats' milk (Tsiplakou et al. 2006), ewes' milk (Mierlita et al. 2011; Soják et al. 2013) and cows' milk (Nantapo et al. 2014). Another possible reason for the variations in the milk fat content (fatty acids) as reported by different authors could be attributed to the variations in the botanical and chemical compositions of the pastures grazed by the different goat breeds (Atașo lu et al. 2009). According to Demeyer and Doreau (1999), difference in the stearic acid content of milk in ruminant animals depends on several factors such as the amount of polyunsaturated fatty acid in the ruminant feed, $\Delta 9$-desaturase activity in the mammary glands and bio-hydrogenation processes in the rumen.

Goat genotypes had a significant influence $(P<0.05)$ on the milk saturated fatty acids, with the milk from Boer goats having higher mean value (73.77\%) when compared with those from Nguni (68.65\%) and non-descript $(71.73 \%)$ goats. The mean values of saturated fatty acids obtained from the three goat genotypes in the current study were higher when compared with those reported by Talpur et al. (2009) from the milk of two different breeds of goats (Pateri and Kamori; 64.37 vs. $59.07 \%$, respectively) and in two different breeds of ewes (Kachi and Kooka; 66.96 vs. $59.00 \%$, respectively). In contrast to our findings, Nantapo et al. (2014) reported a higher value $(78.50 \%$ at late lactation) of saturated fatty acid for dairy cows raised under a pasture-based system. For milk processors, high value of saturated fatty acid in milk may improve the keeping quality and enhance shelf life due to oxidation stability, but may be detrimental to human health by increasing the chances of cardiovascular diseases.

The mean values of myristic acid obtained from Nguni (7.90\%), Boer (9.49\%) and non-descript (9.56\%) goats were comparable to the values $(9.85$ and $9.92 \%$, respectively) reported by Talpur et al. (2009) and Barłowska et al. (2011) in goat milk. However, contrary to our findings, Schmidely et al. (2005) reported a higher proportion of myristic acid (12.03\%) in goat milk. A lower percentage of myristic acid in milk fat appears to be favourable for human health because of their harmful role in atherosclerosis (Pfeuffer and Schrezenmeir 2000).

Health-related fatty acid ratio of n-6/n-3 fatty acid did not differ statistically $(P<0.05)$ among goat genotypes and the time of milk sampling in our study. The mean values of the $n-6 / n-3$ for Nguni, Boer and non-descript goats were low $(1.91 \pm 0.07,1.83 \pm 0.12$ and $1.94 \pm 0.09$, respectively) when compared to those reported by Mierlita et al. (2011) in milk of two ewe breeds, namely Spanca $(4.36 \pm 1.17)$ and Turcana (4.39 \pm 0.28$)$. Conversely, Devle et al. (2012) in their study reported a higher value $(3.96 \pm 0.06)$ of $n-6 / n-3$ fatty acid ratio in milk fat of goats when compared with those reported for Nguni, Boer and non-descript goats in the current study. It is very essential to have a low health-related fatty acid, especially, n-6/n-3 fatty acid ratio in the diet to reduce negative prothrombotic effects caused by increased $n-6$ linoleic acid concentration often seen in most Western diets (Tsiplakou and Zervas 2008).

Furthermore, there was a significant difference $(P<0.05)$ in goat genotypes and the time of milk sampling as observed for ratios of PUFA/SFA, with non-descript goats having a higher mean value $(0.06 \pm 0.002)$ compared with Nguni $(0.05 \pm 0.002)$ and Boer $(0.04 \pm 0.003)$ goats. The PUFA/SFA and n-6/n-3 PUFA ratios are commonly used to measure the nutritional value and consumer health of animal fat (Pilarczyk et al. 2015). Generally, a ratio of PUFA to SFA above 0.45 and a ratio of $n-6 / n-3$ below 4.0 are required in the diet to combat some diseases such as coronary heart disease and cancer (Simopoulos 2002). In the present study, the PUFA/SFA ratios (0.06, 0.05 and 0.04 for non-descript, Nguni and Boer goats, respectively) were considerably lower than the recommended values, whereas the $n-6 / n-3$ ratios for Nguni, Boer and non-descript goats $(1.91,1.83$ and 1.94, respectively) were within the recommended values. The reason for the lower 
PUFA/SFA ratios from the observed goat genotypes and that of the recommended values could be due to differences in the location of study and variation in feed management (Renna et al. 2012).

The atherogenicity index is a criterion for the level and interrelation of some fatty acids that may have atherogenic properties. There was no significant difference $(P<0.05)$ in atherogenicity index of Nguni, Boer and non-descript goat genotypes. However, the mean values obtained for atherogenicity index for Nguni, Boer and non-descript goats (2.34, 2.60 and 2.35 , respectively) were in line with the results reported in previous studies for goats' milk (Bouattour et al. 2008). According to the findings by Tsiplakou et al. (2006) and Renna et al. (2012), milk from grazing goats had better quality parameters for human nutrition when compared with those fed with diets based on preserved forages and concentrates. The values of atherogenicity index observed for Nguni, Boer and non-descript goats may be related, for example, to the increased concentration of the conjugated linoleic acid content, which is now described as having anti-atherogenic properties (Cieslak et al. 2010). Diets with a high atherogenicity index and $n-6 / n-3$ ratio are considered harmful to health (Tsiplakou and Zervas 2008; Pilarczyk et al. 2015). It is important to have milk with lower values of these variables, which can counteract the effects of high omega- 6 diets which is a typical characteristic of most countries in the west.

\section{Conclusions}

In this study, it was evident that goat genotypes and the time of milk sampling had a significant influence in the milk fat of Nguni, Boer and non-descript goats. This demonstrates the fact that goat genotypes markedly influenced the fatty acid profile in goat milk fat, with particular reference to linoleic, conjugated linoleic, $\alpha$-linolenic and eicosopentaenoic acids, which are considered beneficial to human health.

\section{Acknowledgements}

The authors wish to thank Govan Mbeki Research Development Centre (GMRDC), University of Fort Hare, and the South African System Analysis Centre for their intellectual impact and financial assistance.

\section{Funding}

This research was sponsored by the Department of Science and Technology/ National Research Foundation (Project T359) and the DST/NRF collaborative postgraduate training programme (IUD: 92544).

\section{Availability of data and materials}

Kindly contact the author for data requests.

\section{Authors' contributions}

EMI and VM conceptualized and designed the work. EMI collected and analyzed the data. EMI and VM visualized the results. EMI wrote the paper. AJA, VM and AH provided laboratory facilities for analyzing the milk samples and financial support for the experiment. All authors read and approved the final manuscript.

\section{Competing interests}

The authors declare that they have no competing interests.

\section{Publisher's Note}

Springer Nature remains neutral with regard to jurisdictional claims in published maps and institutional affiliations.

\section{Author details}

${ }^{1}$ Faculty of Science and Agriculture, Department of Livestock and Pasture Science, University of Fort Hare, Private Bag X1314, Alice 5700, South Africa. ${ }^{2}$ MPED Research Center, Department of Botany, University of Fort Hare, Alice 5700, South Africa. ${ }^{3}$ Faculty of Natural and Agricultural Sciences, Department of Animal Science, University of Free State, P.O. Box 339, Bloemfontein 9300, South Africa.

Received: 16 September 2018 Accepted: 10 February 2019

Published online: 28 February 2019

\section{References}

Atașoǧlu, C., C. Uysal-Pala, and Y. Karagül-Yüceer. 2009. Changes in milk fatty acid composition of goats during lactation in a semi-intensive production system. Archiv Tierzucht 52: 627-636 archtierz.fbn-dummerstorf.de/pdf/2009/at09p627.pdf.

Barłowska, J., M. Szwajkowska, Z. Litwi'nczuk, and J. Król. 2011. Nutritional value and technological suitability of milk from various animal species used for dairy production. Comprehensive Reviews in Food Science and Food Safety 10: 291-302. https://doi.org/10.1111/j.1541-4337.2011.00163.x.

Bouattour, M.A., R. Casals, E. Albanell, X. Such, and G. Caja. 2008. Feeding soybean oil to dairy goats increases conjugated linoleic acid in milk. Journal of Dairy Science 91: 2399-2407. https://doi.org/10.3168/jds.2007-0753.

Chilliard, Y., and A. Ferlay. 2004. Dietary lipids and forage interactions on cow and goat milk fatty acid composition and sensory properties. Reproduction Nutrition Development 45: 467-492 http://doi.org/10.1051/rnd:2004052.

Cieslak, A., J. Kowalczyk, M. Czauderna, A. Potkanski, and M. Szumacher-Strabel. 2010. Enhancing unsaturated fatty acids in ewe's milk by feeding rapeseed or linseed oil. Czech Journal of Animal Science 55: 496-504 https://doi.org/10. 17221/1704-CJAS

D'urso, S., M.I. Cutrignelli, S. Calabro, F. Bovera, R. Tudisco, V. Piccolo, and F. Infascelli. 2008. Influence of pasture on fatty acid profile of goat milk. Journal of Animal Physiology and Animal Nutrition 92: 405-410. https://doi.org/10. 1111/j.1439-0396.2008.00824.x

Demeyer, D., and M. Doreau. 1999. Targets and procedures for altering meat and milk lipids. Proceedings of the Nutrition Society 58: 593-607. https://doi.org/10. 1017/S0029665199000786.

Devle, H., I. Vetti, C.F. Naess-Andresen, E. Rukke, G. Vegarud, and D. Ekeberg. 2012 A comparative study of fatty acid profiles in ruminant and non-ruminant milk. European Journal of Lipid Science and Technology 114: 1036-1043. https://doi.org/10.1002/ejlt.201100333.

Folch, J., M. Lees, and G.H. Sloane-Stanley. 1957. A simple method for the isolation and purification of total lipids from animal tissue. Journal of Biological Chemistry 226: 497-509.

Idamokoro, E.M., P.J. Masika, and V. Muchenje. 2016. Vachellia karroo leaf meal: A promising non-conventional feed resource for improving goat production in low-input farming systems of Southern Africa. African Journal of Range and Forage Science 33: 141-153. https://doi.org/10.2989/10220119.2016.1178172.

Mierlita, D., St. Daraban, and F. Lup. 2011. Effects of breed on milk fatty acid profile in dairy ewes, with particular reference to cis-9, trans-11 conjugated linoleic acid. South African Journal of Animal Science 41: 223-231. https://doi. org/10.4314/sajas.v41i3.4.

Mills, S., R.P. Ross, C. Hill, G.F. Fitzgerald, and C. Stanton. 2011. Milk intelligence: Mining for bioactive substances associated with human health. International Dairy Journal 21: 377-401. https://doi.org/10.1016/j.idairyj.2010.12.011.

Mucina, L., and M.C. Rutherford, eds. 2011. The vegetation of South Africa, Lesotho and Swaziland. Strelitzia 19. Pretoria: South African Biodiversity Institute.

Myburgh, J., G. Osthoff, A. Hugo, M. de Wit, K. Nel, and D. Fourie. 2012. Comparison of the milk composition of free-ranging indigenous African cattle breeds. South African Journal of Animal Science 42: 1-14. https://doi. org/10.4314/sajas.v42i1.1.

Nantapo, C.T.W., V. Muchenje, and A. Hugo. 2014. Atherogenicity index and health-related fatty acids in different stages of lactation from Friesian, Jersey and Friesian $\times$ Jersey cross cow milk under a pasture-based dairy system. Food Chemistry 146: 127-133. https://doi.org/10.1016/j.foodchem.2013.09.009. 
Park, P.W., and R.E. Goins. 1994. In situ preparation of fatty acid methyl esters for analysis of fatty acid composition in foods. Journal of Food Science 59: 12621266. https://doi.org/10.1111/j.1365-2621.1994.tb14691.x.

Park, Y.W. 1994. Hypoallergenic and therapeutic significance of goat milk. Small Ruminant Research 14: 151-159. https://doi.org/10.1016/0921-4488(94)90105-8.

Pesek, M., E. Spicka, and E. Samkova. 2005. Comparison of fatty acid composition in milk fat of Czech Pied cattle and Holstein cattle. Czech Journal of Animal Science 50: 122-128.

Pfeuffer, M., and J. Schrezenmeir. 2000. Bioactive substances in milk with properties decreasing risk of cardiovascular disease. British Journal of Nutrition 84: $155-159$

Pilarczyk, R., J. Wójcik, P. Sablik, and P. Czerniak. 2015. Fatty acid profile and health lipid indices in the raw milk of Simmental and Holstein-Friesian cows from an organic farm. South African Journal of Animal Science 45: 30-38. https://doi.org/10.4314/sajas.v45i1.4.

Renna, M., C. Lussiana, P. Cornale, R. Fortina, and A. Mimosi. 2012. Changes in goat milk fatty acids during abrupt transition from indoor to pasture diet. Small Ruminant Research 108: 12-21. https://doi.org/10.1016/j.smallrumres. 2012.06.007.

Schmidely, P., P. Morand-Fehr, and D. Sauvant. 2005. Influence of extruded soybeans with or without bicarbonate on milk performance and fatty acid composition of goat milk. Journal of Animal Science 88: 757-765. https://doi. org/10.3168/jds.S0022-0302(05)72739-9.

Silanikove, N., G. Leitner, U. Merin, and C.G. Prosser. 2010. Recent advances in exploiting goat's milk: Quality, safety and production aspects. Small Ruminant Research 89: 110-124. https://doi.org/10.1016/.smallrumres.2009.12.033.

Simopoulos, A.P. 2002. The importance of the ratio of omega-6/omega-3 essential fatty acids. Biomedicine Pharmacotherapy 56: 365-379. https://doi. org/10.1016/S0753-3322(02)00253-6.

Soják, L., J. Bla`sko, R. Kubinec, R. Górová, G. Addová, I. Ostrovsky, and M. Margetín. 2013. Variation among individuals, breeds, parities and milk fatty acid profile and milk yield of ewes grazed on pasture. Small Ruminant Research 109: 173-181. https://doi.org/10.1016/j.smallrumres.2012.07.017.

Talpur, F.N., M.L. Bhanger, and N.N. Memon. 2009. Milk fatty acid composition of indigenous goat and ewe breeds from Sindh, Pakistan. Journal of Food Composition and Analysis 22: 59-64. https://doi.org/10.1016/j.jfca.2008.09.005.

Thohari, I.. H. Purnomo, L.E. Radiati, and Z. Fanani. 2012. A developmental strategy for consumer buying - Choices of goat milk kefir in East Java. Livestock Research and Rural Development 24.

Tsiplakou, E., K.C. Mountzouris, and G. Zervas. 2006. Concentration of conjugated linoleic acid in grazing sheep and goat milk fat. Livestock Science 103: 74-84. https://doi.org/10.1016/j.livsci.2006.06.002.

Tsiplakou, E., and G. Zervas. 2008. Comparative study between sheep and goats on rumenic acid and vaccenic acid in milk fat under the same dietary treatments. Livestock Science 119: 87-94. https://doi.org/10.1016/j.livsci.2008.03.009.

Tsiplakou, E., and G. Zervas. 2013. The effect of fish and soybean oil inclusion in goat diet on their milk and plasma fatty acid profile. Livestock Science 155: 236-243. https://doi.org/10.1016/j.livsci.2013.05.020.

Tyagi, A., H. Kaur, N. Kewalramani, and K.K. Singhal. 2010. Effect of monensin supplementation on conjugated linoleic content in the milk of cow and buffaloes. Indian Journal of Animal Science 80: 49-52.

Ulbricht, T.L.V., and Southgate, D.A.T. 1991. Coronary heart disease: Seven dietary factors. Lancet 338: 985-992. https://doi.org/10.1016/0140-6736(91)91846-M.

\section{Submit your manuscript to a SpringerOpen ${ }^{\circ}$ journal and benefit from:}

- Convenient online submission

- Rigorous peer review

- Open access: articles freely available online

- High visibility within the field

- Retaining the copyright to your article

Submit your next manuscript at $\boldsymbol{\nabla}$ springeropen.com 